\title{
DESAIN APLIKASI MOBILE PANDUAN SHOLAT DAN DOA UNTUK ANAK GANGGUAN PENDENGARAN
}

\author{
Bambang Robi'in ${ }^{1}$, Zahra Arwaning Tyas ${ }^{2}$ \\ 1eure_bbg@yahoo.com, 22zahraatyas@unisayogya.ac.id \\ ${ }^{1}$ Universitas Ahmad Dahlan, ${ }^{2}$ Universitas Aisyiyah Yogyakarta
}

\begin{abstract}
Abstrak
Anak-anak dengan gangguan pendengaran merupakan anak-anak yang mengalami kesulitan dalam belajar. Mereka memiliki keterbatasan kosakata dan bahasa dalam berkomunikasi sehingga menghambat proses belajar. Mereka membutuhkan cara khusus dalam belajar dan biasanya menempuh pendidikan pada sekolah luar biasa bagian B (SLBB). Siswa kelas dasar 2 pada SLB B Karnnamanohara mengalami kesulitan dalam belajar sholat dan doa sehari-hari. Hampir semua siswa kelas dasar 2 belum bisa mengucapkan bacaan sholat dan doa sehari-hari. Mereka membutuhkan sumber belajar yang menarik dan sesuai dengan karakteristik mereka. Penelitian ini bertujuan untuk merancang aplikasi mobile multimedia panduan sholat dan doa sehari-hari untuk anak-anak dengan gangguan pendengaran. Metode penelitian terdiri dari lima tahap yaitu pengumpulan data, analisis data, pembuatan storyboard, desain prototipe, dan evaluasi prototipe. Penelitian ini telah berhasil merancang aplikasi mobile multimedia panduan sholat dan doa untuk anak-anak gangguan dengar sesuai dengan kebutuhan user yang memiliki karakterisitik berbeda dengan pengguna pada umumnya. Hasil penelitian menunjukan bahwa desain prototipe aplikasi mobile multimedia panduan sholat dan doa untuk anak-anak dengan gangguan pendengaran telah memenuhi kebutuhan user dengan nilai evaluasi sebesar 4,42 dari skala 5 .
\end{abstract}

Kata Kunci: Multimedia, Applikasi Mobile, Panduan Sholat, Doa, Gangguan Dengar

\begin{abstract}
Children with hearing loss are children who experience learning difficulties. They have limited vocabulary and language in communication that hampers the learning process. They need a special way of learning and are usually educated in special schools. Level 2 elementary students at SLB B Karnnamanohara have difficulty learning prayer and daily prayer. Almost all elementary level 2 students cannot pronounce daily prayers and prayers. They need interesting learning resources and according to their characteristics. This study aims to design multimedia mobile application of prayer and daily prayers guides for children with hearing loss. The research method consists of five stages: data collection, data analysis, storyboard making, prototype design, and prototype evaluation. This research has been designed to multimedia mobile applications of prayer and prayers guides for children hearing impairments according to the needs of users who have different characteristics with users in general. The results showed that the prototype design of the multimedia mobile application prayer and prayer daily guides for children with hearing loss had met the needs of users with evaluation values of 4.42 from a scale of 5 .
\end{abstract}

Keywords: Multimedia, Mobile Application, Prayer Guide, Daily Prayer, Hearing Loss

\section{Pendahuluan}

Anak tuna rungu atau anak dengan gangguan pendengaran merupakan anak yang kehilangan kemampuan untuk mendengar sebagaimana kemampuan yang dimiliki oleh anak-anak normal. Anakanak tersebut kehilangan kemampuan mendengar yang dapat terjadi sejak lahir atau dalam masa pertumbuhannya. Secara garis besar tingkat gangguan pada anak-anak tuna rungu dapat dikelompokkan menjadi gangguan berat, gangguan sedang dan gangguan ringan.

Kehilangan kemampuan mendengar mengakibatkan anak tidak pernah mengetahui apa itu suara atau bunyi sehingga anak tersebut juga mengalami kesulitan dalam memproduksi suara/bunyi. Kenyataanya, suara atau bunyi menjadi komponen utama dalam komunikasi. Hal itu juga mengakibatkan pemahaman anak tuna rungu terhadap bahasa dan penggunaanya menjadi terhambat. Ketidakmampuan mendengar berbeda dengan penyandang cacat lainnya, karena adanya bahasa lain yang mengkompensasi bahasa lisan atau lisan dan dikenal sebagai bahasa isyarat[1]. Terdapat tiga teknik komunikasi yang dapat dipilih oleh seorang dengan gangguan pendengaran yaitu dengan bahasa isyarat, teknik oral (speechreading), atau dengan memanfaatkan sisa pendengaran dengan bantuan alat bantu dengar atau dengan implan koklea. 
Anak-anak dengan gangguan pendengaran perlu cara khusus untuk belajar[2]. Mereka membutuhkan guru khusus yang mengetahui keadaan mereka secara psikologis, untuk mengetahui bagaimana berkomunikasi dengan mereka, bagaimana mengucapkan kata, dan memahaminya[3]. Kurikulum harus beradaptasi untuk memenuhi kebutuhan individu dan pendekatan yang fleksibel [4]. Keterbatasan pada anak tuna rungu menjadi perhatian khusus sehingga proses pendidikan yang perlu diikuti oleh anak tuna rungu berbeda dengan proses pendidikan pada anak nomal. Salah satu solusi pendidikan bagi anak tuna rungu adalah sekolah luar biasa bagian $\mathrm{B}$.

Sekolah Luar Biasa (SLB) B Karnnamanohara Yogyakarta merupakan sekolah luar biasa yang memberikan layanan pendidikan pada anak-anak tuna rungu.Jenjang pendidikan yang diselenggarakan bertingkat yaitu kelas Latihan, Taman, Dasar, SMP dan SMA. Anak-anak pada jenjang pendidikan Dasar (SD) kelas 1 dan 2 telah memiliki kemampuan dasar untuk berkomunikasi menggunakan bahasa Indonesia sederhana. Siswa telah memiliki kemampuan untuk baca tulis, dan memiliki kemampuan untuk berkomunikasi secara oral (speechreading). Khusus bagi siswa yang beragama muslim, mereka mengalami kesulitan dalam belajar tentang sholat dan doa sehari-hari. Kesulitan ini terjadi karena bacaan sholat dan doa sehari-hari menggunakan tulisan dan bahasa arab. Tulisan dan bahasa arab ini apabila dituliskan dalam bahasa indonesia akan mengalami perbedaan ucapan antara tulisan dan cara membaca, sebagai contoh adalah tulisan "ra" akan dibaca "ro". Disamping itu pelajaran agama lebih banyak mengandung materi yang sifatnya abstrak, sedangkan anak tuna rungu cenderung lebih mudah untuk mempelajari sesuatu yang bersifat real seperti benda, tempat, dan lain sebagainya.

Multimedia merupakan teknologi yang berkembang dengan sangat pesat. Lima komponen multimedia yaitu teks, suara, gambar, animasi, dan video yang digunakan untuk menyampaikan informasi secara lengkap. Berdasarkan survey pendahulu, anak-anak dengan gangguan pendengaran ini memiliki ketertarikan terhadap multimedia melaui perangkat smartphone yang memiliki fitur komunikasi canggih[5]. Teknologi Smartphone sebagai perangkat mobile telah mengalami perkembangan yang sangat pesat dan menjadi bagian dari aktifitas sehari-hari anak dalam kegiatan belajar[6][7].

Kemajuan teknologi baru-baru ini telah menghasilkan banyak pengembangan smartphone cerdas[8]. Salah satu teknologi modern yang berkembang adalah perangkat lunak aplikasi, umumnya dikenal sebagai "'apps" untuk perangkat mobile[9]. Saat ini belum banyak penelitian tentang penggunaan ponsel cerdas dalam pembelajaran ibadah untuk anak-anak dengan gangguan pendengaran. Penelitian ini mengusulkan perancangan suatu aplikasi mobile multimedia panduan belajar sholat dan doa sehari-hari untuk anak-anak dengan gangguan pendengaran.

Terdapat beberapa penelitian terdahulu yang mendasari dan dijadikan sebagai acuan sehingga aplikasi mobile multimedia panduan sholat dan doa sehari hari untuk anak dengan gangguan pendengaran ini diusulkan dalam penelitian ini.

Penelitian yang berjudul An analytical study of mobile applications for Hajj and Umrah services[9]. Penelitian ini fokus pada studi analisa aplikasi yang diperuntukan untuk ibadah haji dan umroh. Metode penelitian yang digunakan terbagi menjadi dua bagian yaitu review proccess dan case study.

Penelitian yang berjudul Quality Framework for Assessment of Multimedia Learning Materials Version 1.0[10]. Fokus dalam penelitian ini adalah pengembangan sebuah instrument untuk mengukur suatu kualitas material dari multimedia pembelajaran.Framework ini disebut dengan MLM versi 1.0.

Penelitian yang berjudul Design and Development of Multimedia Pronunciation Learning Management System for Non-Native English Speakers[11]. Penelitian ini merupakan penelitian tentang perancangan dan pengembangan sistem manajemen pembelajaran pronounciation dengan multimedia. Pengembangan aplikasi dengan pendekatan model Alessi and Trollip ISD.

Penelitian yang berjudul The design and testing of multimedia for teaching arithmetic to deaf learners[12]. Penelitian ini berfokus pada bagaimana merancang dan menguji aplikasi multimedia untuk mengajar aritmatika pada anak tuna rungu.

Penelitian terdahulu tersebut telah mendasari dan menjadi acuan daam penelitian ini. meskipun demikian, penelitian ini memiliki perbedaan dengan penelitian-penelitian sebelumnya baik dari segi metode maupun domainnya. Penelitian ini melalui beberapa tahapan yaitu studi literatur dan lapangan, analisis kebutuhan, membuat story board, desain prototipe, dan evaluasi prototype.Penelitian ini melibatkan ahli multimedia dan guru SLB B Karnnamanohara untuk melakukan evaluasi prototipe apakah sudah sesuai dengan kebutuhan user atau belum. 


\section{Metode}

Metode yang digunakan dalam penelitian ini terdiri dari 5 tahap yaitu tahap pengumpulan data, tahap analisis kebutuhan, membuat story board, desain prototype, dan evaluasi prototipe. Langkahlangkah penelitian ini terlihat seperti pada gambar 1.

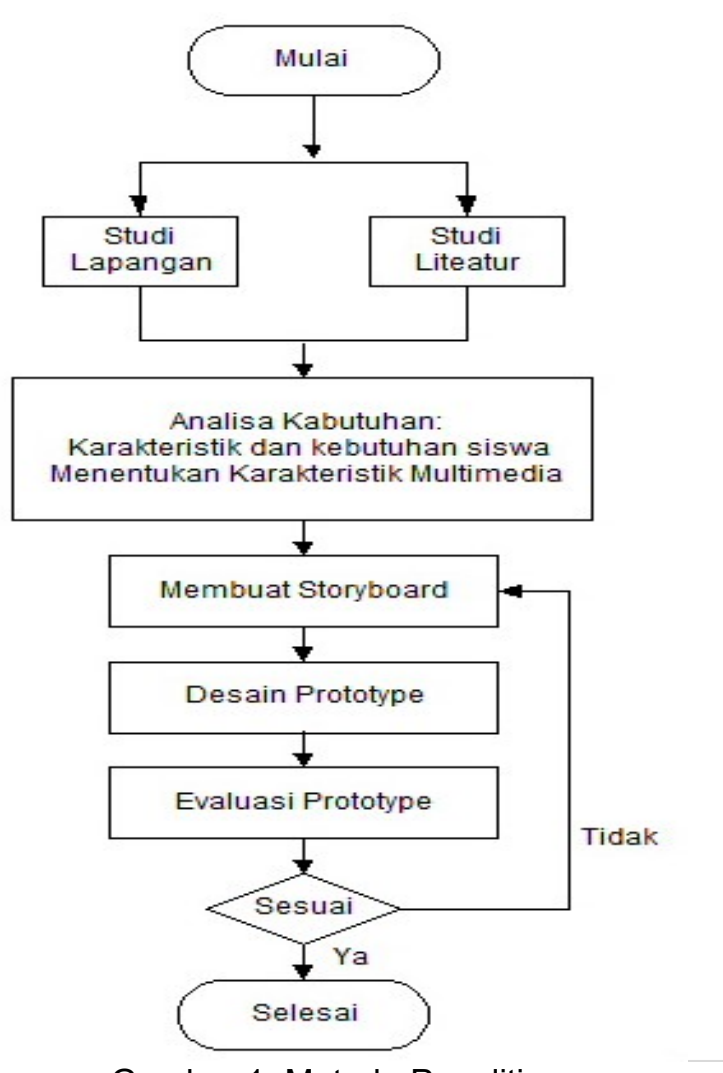

\subsection{Pengumpulan Data}

Gambar 1. Metode Penelitian

Pada tahap ini terdapat dua aktifitas utama yaitu studi literatur dan studi lapangan.Studi literatur dilakukan dengan mempelajari referensi yang sesuai dengan topik penelitian.Studi ini dilakukan untuk memperoleh informasi-informasi yang berhubungan dengan topik penelitian.Studi lapangan dilakukan dengan melakukan obervasi dan wawancara di SLB B Karnnamanohara Yogyakarta. Pada studi lapangan dilakukan observasi terhadap siswa kelas Dasar 2 untuk mengetahui karakteristik pengguna. Selain itu juga dilakukan wawancara pada orang tua dan guru untuk mendapatkan datadata pedukung.

\subsection{Analisa Kebutuhan}

Tahap ini adalah tahap analisa kebutuhan yang meliputi dua aktifitas yaitu mengidentifikasi karakteristik dan kebutuhan user dan mengidentifikasi karakteristik multimedia pembelajaran yang akan dibuat. Tahap ini akan menghasilkan spesifikasi kebutuhan user dan spesifikasi karakteristik multimedia pembelajaran sholat dan doa untuk anak-anak dengan gangguan pendengaran.

\subsection{Pembuatan Storyboard}

Pembuatan storyboard merupakan tahap pembuatan papan cerita yang menggambarkan bagaimana sebuah aplikasi multimedia akan berjalan. Papan cerita menggambarkan bagaimana komponen multimedia (teks, gambar, suara, video, dan animasi) diterapkan dalam aplikasi panduan sholat dan doa untuk anak-anak gangguan pendengaran. Dalam pembuatan storyboard ini mengacu pada kebutuhan user akan materi pembelajaran dan karakteristik multimedia.

\subsection{Desain Prototipe}

Desain prototipe merupakan tahap desan dan pembuatan prototipe mobile aplikasi multimedia penduan sholat dan doa untuk anak-anak dengan gangguan pendengaran. Desain dan pembuatan prototipe ini didasarkan pada papan cerita yang telah dibuat sebelumnya. 


\subsection{Evaluasi Prototipe}

Tahap evaluasi prototipe adalah tahap untuk melakukan evaluasi terhadap prototipe yang telah dibuat sebelumnya.Tahap ini digunakan untuk menilai apakah prorotipe yang dibuat telah memenuhi kebutuhan user atau tidak. Apakah prorotipe yang dibuat telah sesuai dengan spesifikasi kebutuhan user dan karakteristik multimedia panduan sholat dan doa untuk anak-anak dengan gangguan dengar atau belum. Jika hasil evaluasi menunjukan bahwa prototipe tersebut belum memenuhi maka langkah selanjutnya adalah melakukan desain ulang sampai dengan terpenuhi kebutuhan tersebut.Evaluasi prototipe ini dilakukan oleh pakar multimedia dan guru SLBB Karnamanohara Depok Sleman Yogyakarta.

\section{Hasil dan Pembahasan}

\subsection{Karakteristik Pengguna}

Analisis kebutuhan digunakan untuk mengetahui bagaimana karakteristik kebutuhan user dan karakteristik multimedia.Analisis ini di lakukan melalui studi literatur dan observasi di lapangan yaitu pada siswa kelas dasar 2 pada SLB B Karnnamanohara Depok Sleman Yogyakarta. Hasil analisa berupa karaketeristik kebutuhan user dan karakteristik multimedia yang ditunjukan pada tabel 1.

Tabel 1. Karakteristik Kebutuhan User dan Karakteristik Multimedia

\begin{tabular}{cl}
\hline \multicolumn{1}{c}{ Analisa } & Hasil \\
\hline Karakteristik Kebutuhan User & 1. Usia anak kelas dasar 2 (9-11 tahun) \\
2. Semua siswa kelas dasar 2 adalah muslim \\
3. Memiliki kelebihan terhadap visualisasi \\
4. Menggunakan ABM (Hearing aids) \\
5. Kemampuan memanfaatkan sisa pendengaran baru sampai \\
6. Berkomunikasi dengan teknik lipsreading (membaca gerak \\
7. Kemampuan akademik yang rendah \\
8. Sudah dapat membaca dengan tulisan bertipe handwriting \\
9. Sedikit memiliki kosakata, memahami bahasa \\
10. Anak-anak baru mempelajari doa mau makan dan doa mau \\
11. Anak-anak belum mempelajari doa bacaan sholat \\
12. Anak-anak sudah mempelajari gerakan sholat \\
13. Metode pembelajaran di kelas menggunakan metode MMR \\
(Metode Materna Reflektif) dan gambar sebagai media \\
ilustrasi \\
14. Di rumah anak-anak sudah mengamalkan doa mau makan \\
15. Anak-anak sudah terbiasa menggunakan HP android \\
1. Meminimalisir kontent yang membingungkan \\
2. Mengurangi efek suara \\
3. Mengurangi narasi \\
4. Menonjolkan elemen visual \\
5. Segmented content (adanya pembagian konten) \\
6. Menampilkan video lipsreading dengan suara \\
7. Menggunakan teks bertipe handwriting \\
8. Kombinasi warna yang cerah dan konstras
\end{tabular}

Hasil analisa yang ditunjukan pada tabel 1 tersebut merupakan data yang akan digunakan untuk membuat storyboard dan prototipe aplikasi.

\subsection{Desain Menu}

Desain menu aplikasi pada panduan sholat dan doa untuk anak-anak dengan gangguan pendengaran ini terdiri dari 4 menu utama. Dua menu utama yaitu panduan sholat dan panduan doa memiliki sub menu masing-masing menu belajar dan menu kuis. Struktur desain menu ini terlihat seperti pada gambar 2. 
ILKOM Jurnal Ilmiah Volume 10 Nomor 3 Desember 2018

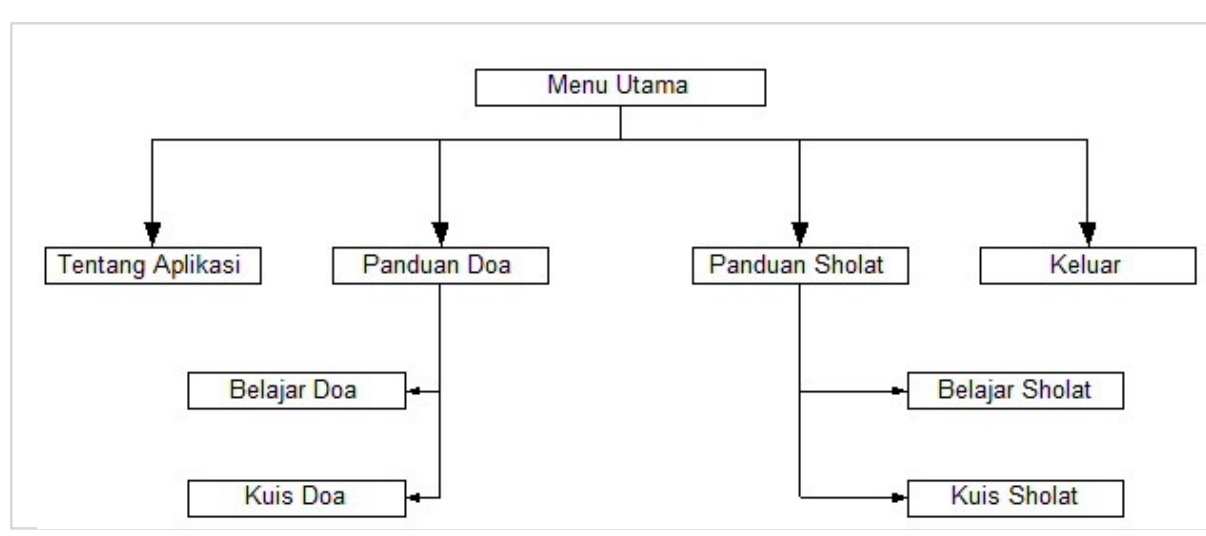

Gambar 2. Desain Menu

\subsection{Storyboard}

Storyboard merupakan papan cerita sebagai ilustrasi yang menggambarkan bagaimana aplikasi mobile multimedia panduan sholat untuk anak-anak gangguan pendengaran ini akan berjalan. Papan cerita ini dibuat untuk menunjukkan komponen multimedia yang dilengkapi dengan arahan grafis dan keterangan. Gambar 3 adalah desain storyboard dari menu utama, panduan doa, dan panduan sholat.
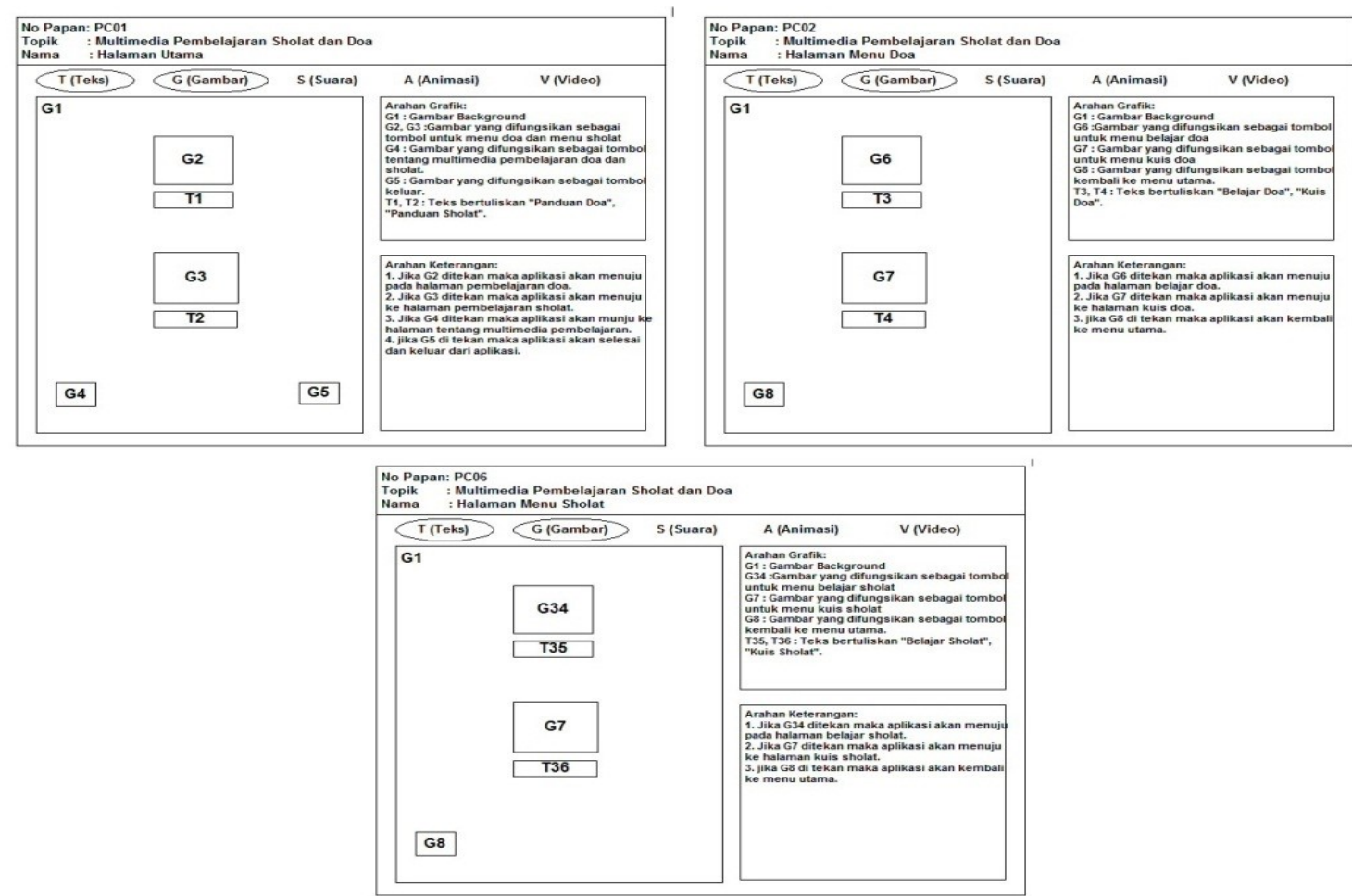

Gambar 3.Storyboard Menu Utama

Pada menu panduan doa terdapat tiga halaman yaitu belajar doa, detil doa,dan kuis doa. Storyboard dari panduan doa terlihat seperti pada gambar 4 . 


\section{ILKOM Jurnal Ilmiah Volume 10 Nomor 3 Desember 2018}

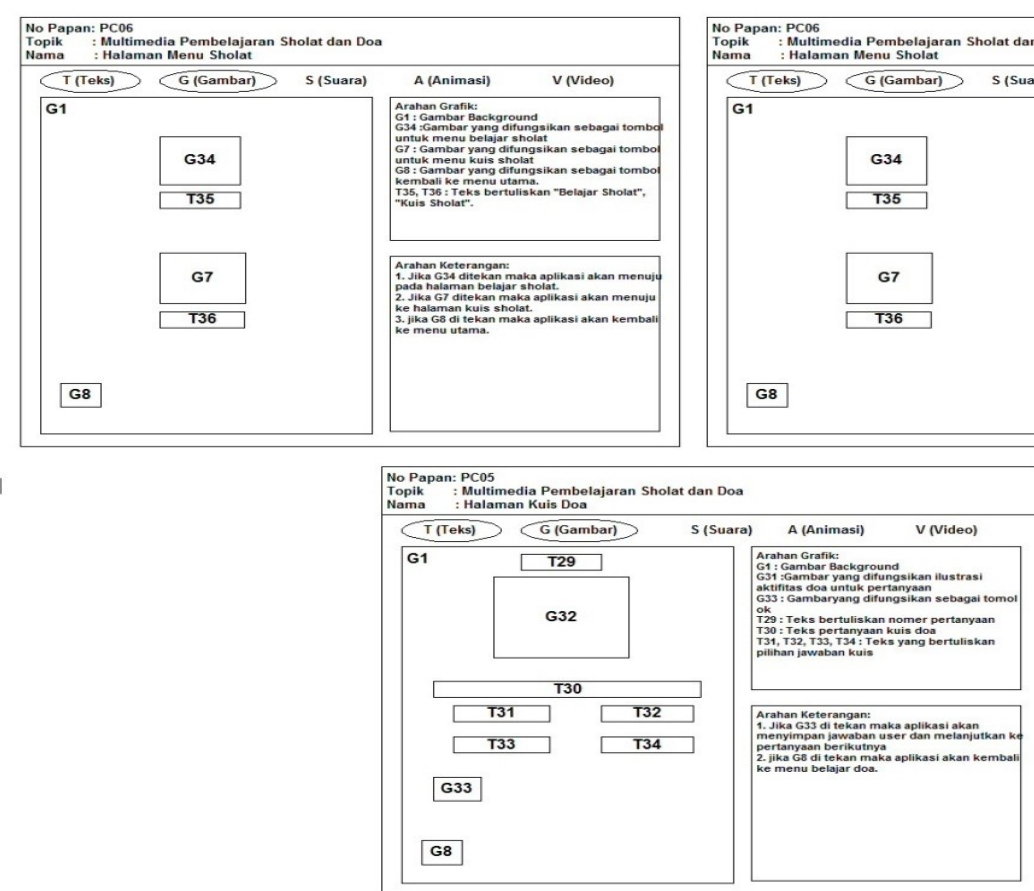

Gambar 4.Storyboard Panduan Doa

Pada menu panduan sholat terdapat tiga halaman yaitu belajar sholat, detil sholat,dan kuis sholat. Storyboard dari panduan sholat terlihat seperti pada gambar 5 .
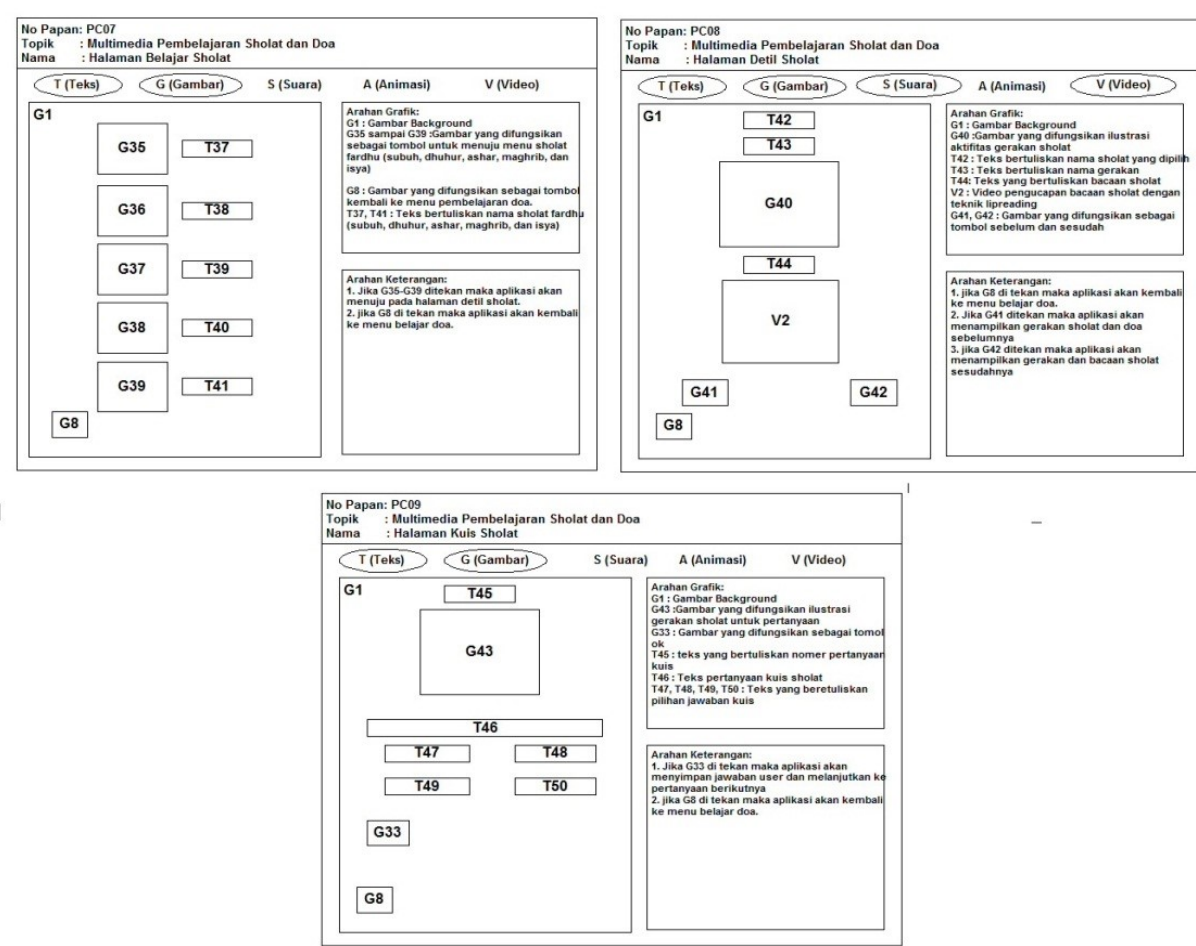

Gambar 5.Storyboard Panduan Sholat 


\subsection{Desain Prototipe}

Desain prototipe merupakan tahap yang bertujuan untuk membuat prototipe aplikasi mobile multimedia panduan sholat dan doa untuk anak-anak dengan gangguan pendengaran. Melakukan desain prototipe didasarkan pada desain papan cerita yang telah dibuat sebelumnya. Desain prototipe aplikasi mobile multimedia panduan sholat dan doa untuk anak-anak gangguan pendengara terlihat seperti pada gambar 6 .

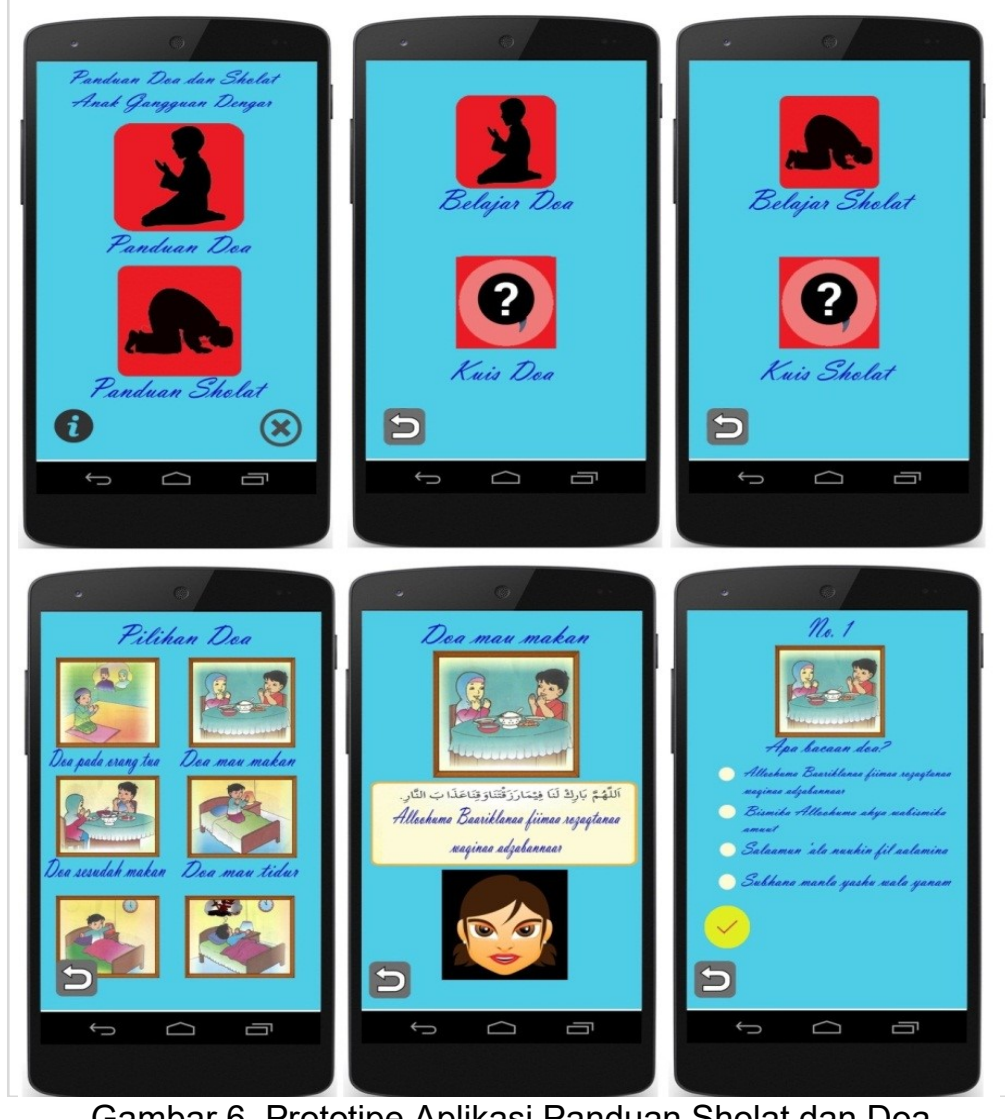

Gambar 6. Prototipe Aplikasi Panduan Sholat dan Doa

\subsection{Desain Prototipe}

Setelah prototipe selesai dibuat, tahap selanjutnya adalah melakuakn evaluasi terhadap hasil prototipe.Evaluasi ini dilakuakn untuk mengetahui dan menilai apakah prototipe telah sesuai dengan kebutuhan user dan karekteristik multimedia dari haril analisa.Evaluasi prototipe dilakukan oleh ahli multimedia dan guru SLB B Karnnamanohara.Tujuh pertanyaan yang menjadi indikator untuk melakukan evaluasi prototipe diberikan kepada responden yaitu ahli multimedia dan guru SLB B Karnnamanohara.Jumlah responden dalam evaluasi prototipe adalah 10 orang yang terdiri dari 3 orang ahli multimedia dan 7 orang guru SLB B Karnnamanohara.Hasil evaluasi prototipe ditunjukan pada tabel 2.

Tabel 2. Hasil Evaluasi Prototipe

\begin{tabular}{|c|c|c|c|c|c|c|}
\hline \multirow{2}{*}{ No } & \multirow{2}{*}{ Pertanyaan } & STS & TS & $\mathrm{R}$ & $\mathrm{S}$ & SS \\
\hline & & 1 & 2 & 3 & 4 & 5 \\
\hline 1 & $\begin{array}{l}\text { Prototype telah dideskripsikan sesuai dengan } \\
\text { tujuan Apliakasi yaitu panduan sholat dan doa }\end{array}$ & & & & 7 & 3 \\
\hline 2 & $\begin{array}{l}\text { Materi panduan pada prototype telah sesuai } \\
\text { dengan kebutuhan siswa }\end{array}$ & & & & 5 & 5 \\
\hline 3 & $\begin{array}{l}\text { Komponen pada prototype telah memenuhi } \\
\text { kebutuhan panduan sholat dan doa }\end{array}$ & & & & 6 & 4 \\
\hline 4 & $\begin{array}{l}\text { Materi pada prototype terdiri dari cara belajar dan } \\
\text { evaluasi belajar (kuis) }\end{array}$ & & & & 3 & 7 \\
\hline 5 & $\begin{array}{l}\text { Materi sholat pada prototype meliputi sholat lima } \\
\text { waktu }\end{array}$ & & & & 3 & 7 \\
\hline
\end{tabular}




\section{ILKOM Jurnal IImiah Volume 10 Nomor 3 Desember 2018}

\begin{tabular}{lllll}
\hline 6 & Materi doa pada rpototipe meliputi doa aktifitas & & & 7 \\
7 & $\begin{array}{l}\text { sehari hari } \\
\text { Prototype memiliki komponen khusus untuk anak- } \\
\text { anak gangguan pendengaran berupa car } \\
\text { apengucapan dengan lipsreading (gerak bibir) }\end{array}$ & 5 & 5 \\
\hline Total & & 0 & 0 & 32 \\
\hline
\end{tabular}

Hasil penilaian prototype pada 10 responden adalah: $(32 * 4+38 * 5) /(7 \times 10)=(128+190) / 70$ $=4,42$. Dengan demikian, evaluasi prototype dari ahli multimedia dan guru SLBB Karnnamanohara memperoleh nilai 4,42 dari skala 5 .

\section{Kesimpulan dan Saran}

Penelitian ini telah berhasil melakukan perancangan dan pembuatan prototipe aplikasi mobile multimedia pembelajaran sholat dan doa untuk anak-anak gangguan pendengaran. Hasil evaluasi prototipe menunjukan bahwa prototipe ini telah memenuhi kebutuhan user dengan nilai 4,42 dari skala 5. Kesimpulan yang dihasilkan dari penelitian bahwa anak-anak dengan gangguan dengar memiliki keterbatasan dalam kosa kata dan bahasa sehingga prototipe didesain dengan menimalisir kata-kata dan objek yang tidak perlu agar tidak membingungkan pengguna. Pada aplikasi ini, materi pembejalaran sholat baru sebatas pada sholat wajib. Terdapat sholat lain yang memiliki gerakan dan bacaan yang berbeda seperti sholat gerhana dan sholat jezanah. Untuk penelitian selanjutnya, aplikasi dapat dikembangkan untuk pembelajaran sholat tersebut yaitu sholat gerhana dan sholat jenazah.

\section{Terima Kasih}

Terimakasih peneliti sampaikan kepada pihak Direktorat Riset dan Pengabdian Masyarakat, Direktorat Jenderal Penguatan Riset dan Pengembangan, Kementerian Riset Teknologi dan Pendidikan Tinggi yang telah menjadi sponsor dalam penelitian ini.

\section{Daftar Pustaka}

[1] E. E. Abdallah and E. Fayyoumi, "Assistive Technology for Deaf People Based on Android Platform," Procedia - Procedia Comput. Sci., vol. 94, no. Fnc, pp. 295-301, 2016.

[2] N. K. Zirzow, "Students with Hearing Loss," Rural Spec. Educ. Q., vol. 34, no. 3, pp. 33-36, 2015.

[3] M. A. Hussein, "Multimedia Education System for Deaf and Hear Impairment Children," Int. Arab Conf. Inf. Technol., pp. 1-6, 2013.

[4] C. M. Shepherd and M. Alpert, "Using technology to provide differentiated instruction for deaf learners," vol. 16, pp. 1-7, 2015.

[5] A. Dirin and M. Nieminen, "mLUX: Usability and User Experience Development Framework for M-Learning," iJIM, vol. 9, no. 3, pp. 37-51, 2015.

[6] I. K. Yusri, R. Goodwin, and C. Mooney, "Teachers and Mobile Learning Perception: Towards a Conceptual Model of Mobile Learning for Training," Procedia - Soc. Behav. Sci., vol. 176, pp. 425-430, 2015.

[7] M. Khemaja and A. Taamallah, "Towards Situation Driven Mobile Tutoring System for Learning Languages and Communication Skills: Application to Users with Specific Needs.," J. Educ. Technol. Soc., vol. 19, no. 1, pp. 113-128, 2016.

[8] N. Cavus, "Development of an intellegent mobile application for teaching English pronunciation," Procedia - Procedia Comput. Sci., vol. 102, no. August, pp. 365-369, 2016.

[9] E. A. Khan, M. Khaled, and Y. Shambour, "Applied Computing and Informatics An analytical study of mobile applications for Hajj and Umrah services," Appl. Comput. Informatics, 2017.

[10] S. J. A. N. B. S. Mohamad, D. Asirvatham, and H. H. M. Khalid, "Quality Framework for Assessment of Multimedia Learning Materials Version 1.0," Procedia - Soc. Behav. Sci., vol. 67, no. November 2011, pp. 571-579, 2012.

[11] F. P. Por, Z. Mustafa, S. Osman, H. S. Phoon, and S. F. Fong, "Design and Development of Multimedia Pronunciation Learning Management System for Non-Native English Speakers," Procedia - Soc. Behav. Sci., vol. 64, pp. 584-593, 2012.

[12] P. Techaraungrong, S. Suksakulchai, W. Kaewprapan, and E. Murphy, "The design and testing of multimedia for teaching arithmetic to deaf learners," Educ. Inf. Technol., 2015. 